\title{
“DEATH BY ECONOMIC CRISIS": SUICIDE AND SELF-INFLICTED INJURY IN THE EUROPEAN UNION (EU15) DURING THE WORST OF TIMES
}

\author{
ERNESTO R. FERREIRA ${ }^{1}$ - JOÃO D. MONTEIRO² - JOSÉ R. PIRES MANSO³ \\ ${ }^{1}$ Department of Management and Economics, Faculty of Human and Social Sciences, \\ University of Beira Interior, Covilhã, Portugal \\ Email: ferreira@ubi.pt (corresponding author) \\ ${ }^{2}$ Department of Management and Economics, Faculty of Human and Social Sciences, \\ University of Beira Interior, Covilhã, Portugal \\ Email:jdm@ubi.pt \\ ${ }^{3}$ Department of Management and Economics, Faculty of Human and Social Sciences, \\ University of Beira Interior, Covilhã, Portugal \\ Email:pmanso@ubi.pt
}

\begin{abstract}
Can socioeconomic fluctuations explain variations in European Union suicide mortality? To answer this question, we investigate the effect of socioeconomic and demographic factors on (agespecific) male and female suicide rates using a fixed-effects technique and panel data for $15 \mathrm{EU}$ countries, over a time period that leads up to, coincides with, and follows the recession of 2008. The findings show that suicide rates for young and working-age populations are more sensitive to general economic conditions than suicide rates for other age groups, and that male suicide behavior is more responsive than female behavior. In this setting, suicide rates are likely to be higher in countries with lower income, higher unemployment, higher divorce rates, and, most importantly, weaker systems of social protection. Our results, however, raise serious doubts about government involvement in crisis-related mental illness prevention and mental health promotion.
\end{abstract}

Keywords: European sovereign debt crisis, socio-economic policy, suicide mortality

JEL-codes: I12, I18, I38 


\section{INTRODUCTION}

A reality that is often denied by society, death by suicide was defined in 1999, for the first time, as a "public health hazard" by the United States (US) Surgeon General (US Public Health Service 1999). Often under-reported or misclassified as another cause of death in some countries, estimates by the World Health Organization (2014) indicate that 804,000 suicide deaths occurred worldwide in 2012, representing an annual global age-standardized suicide rate of 11.4 per 100,000 persons. Statistically, the mean male-to-female ratio for suicide is 3.5 in high-income countries and 1.5 in low and middle-income countries. With regard to age, adolescents and young adults are among those most affected; suicide accounts for 17.6 percent of all deaths among 15-29-year-olds and is the second leading cause of death globally among this age group. Although the absolute number of suicidal deaths has fallen globally by about 9 percent from 2000 to 2012, and the age-standardized suicide rate has fallen 26 percent during the 12-year period, different patterns are seen by region; the percentage change in total suicidal deaths vary from an increase of app roximately 38 percent in low- and middle-income countries in the African Region to a decrease of 47 percent in low- and middleincome countries in the Western Pacific Region. This difference in mortality rates is even more pronounced when evaluating country-level data. In the European Union (EU), for example, the 2000-2012 change in age-standardized suicide rates ranged from a decline of 51 percent in Slovenia to an increase of 10.5 percent in Greece. Among these 28 countries, 18 (64.3 percent) experienced a drop in age-standardized suicide rates of over 10 percent, 8 (28.6 percent) remained practically unchanged, and only two (7.1 percent) experienced an increase of over 10 percent in age-standardized suicide rates over the 12-year period (WHO 2014). Recently, however, an increase in suicide attempts and actual suicides has been reported across the EU region, especially in countries where anti-crisis policies have been accompanied by harsh austerity measures (Corcoran et al. 2015; Economou et al. 2013; Suhrcke et al. 2012; WHO 2011).

Although the correlation between mental illness and suicide is well documented in the literature, factors over and above psychopathology must be involved and certain kinds of crises are most likely to trigger the extreme stress associated with suicidal behavior (Gvion - Apter 2012). Most common are intense interpersonal crises associated with relational conflict, death of a loved one, or loss of hope and meaning that often accompanies terminal illness. Socioeconomic factors are also relevant to the understanding of suicide. Studies on the relationship between economic downturns and mental health indicate that changes in the economy can increase psychiatric pathology and potentially lead to suicide (Martin-Carrasco 2015; Tapia-Granados - Rodriguez 2015; De Vogli et al. 2013). 
Direct socioeconomic consequences, notably unemployment and loss of income, as well as collateral consequences such as impoverishment, increased inequality, family disruption, and loss of status or social recognition can lead to a variety of mental health problems, most prominently depression, alcoholism and suicide (Christodoulou - Christodoulou 2013; Karanikolos et al. 2013). A corollary of this fact is that recessions appear to be most risky when social safety programs are weak and people face low social support (Modrek et al. 2013).

Although suicide is considered one of five primal areas of the European Pact for Mental Health and Welfare (2008), the economic literature on the relationship between EU suicide rates and the most recent economic recession is rather thin and report data for only one or a limited number of countries (Stuckler et al. 2017; dos Santos et al. 2016; Corcoran et al. 2015; Hegerl et al. 2009). In this study, we aim to further explore specific issues raised by this literature, including the need to address the following research questions: (1) did the unfavorable economic circumstances of the last decade(s) increase health risks and eventually affect suicide mortality in the EU; and (2) if so, why those hit hardest by the crisis and resulting austerity varied greatly. To answer these questions, we extend the typical statistical model of the determinants of suicide to cover sex/age groups and regions most affected and assess whether the type of social spending (e.g. on health and/or welfare expenditure) explained variations in suicide rates across EU countries. Including both measures of public spending may partially account for possible differences in suicide patterns between Southern European (less affluent) countries and EU core countries, where austerity was more modest and safety nets more effective in preventing the growth of social inequalities in health when economic conditions deteriorated (an overview of the EU economic crisis can be found in Skouras 2013). In describing the process under study, our research uses a fixed effects estimator and an unbalanced panel data set that includes variables for fifteen EU countries between 1990 and 2013, a time span that predates, coincides with, and follows the recessionary period. Our choice of methodology relies on evidence gathered by authors like Corcoran et al. (2015), Latif (2015), Reeves et al. (2012), Stuckler et al. (2011), and, in particular, Minoiu and Andrés (2008). In addition to the two "public policy" variables (namely, social welfare and health-specific expenditures), it proposes that the process underlying suicide mortality is a function of income and unemployment levels along with a host of other factors, including alcohol consumption, divorce and total fertility rates. We also include time variables in our models in order to account for possible deterministic trends in the data.

We find that public health expenditure actually had a less significant impact on suicide mortality outcomes than did other social welfare programs including direct income support, housing support and unemployment benefits. Although 
the coefficient estimates on the government variables are economically meaningful, we found weak evidence of the relationship between public intervention in health and suicides. Moreover, the results also confirm the impression conveyed by most of the empirical work on the economics of suicide that the combination of high or rising unemployment, divorce, and lower income were important determining factors of suicide mortality in the general population, or in specific age and sex groups. However, given that these variables have a higher impact (both in terms of statistical significance and magnitude) on male suicide rates than female suicide rates and rates in the younger age group than those in the older age group, it is possible that the determinants of female and elderly suicides may well differ from the ones we propose in this study.

The remainder of this article is organized as follows: Section 2 provides an overview of the economic and sociological literature on suicide. Section 3 discusses the variables used in the baseline specifications. Section 4 describes the methodology and findings. Section 5 concentrates on the discussion, policy implications and the concluding remarks.

\section{THE WIDER CONTEXT}

Explanations of all human behavior in terms of economic conditions have been traced back to Morselli (1881) and Durkheim (1897). Durkheim's belief that societal suicide rates were likely to be influenced by social integration and social regulation form the basis of historical and recent attempts to explain suicide and suicidal behavior (Hamermesh - Soss 1974; Stack, 1989; Ruhm 2000). These studies, like many that followed, converged on the assumption that economic and social factors were likely to influence suicide mortality (Lucey et al. 2005; Minoiu - Andrés 2008; Sareen et al. 2011). Thus, the major global crises that started primarily in developed countries are blamed for having a significant impact on health outcomes (Stuckler et al. 2017; Oyesanya et al. 2015). On this reading, for example, several features of life and death spawning from the US crash in 1929 suggest that overall mortality decreased for almost all ages, while suicide mortality rates increased in the most recessionary years, 1929, 1932, and 1938 (Anderson, 2011; Stuckler et al. 2011; Tapia Granados and Diez Roux, 2009). According to Miller et al. (2009), this pattern of US mortality was repeatedly observed over succeeding recessionary periods. Similar suicide mortality patterns were observed in Southeast Asia and Russia during the economic crises of the late 1990s, and in Europe during periods of rapidly increasing unemployment between 1970 and 2009 (Ruhm, 2015: Chang et al. 2009; 
Stuckler et al. 2009). In 2009, according to Chang et al. (2013), an analysis of 54 countries showed an excess of 4,884 suicides compared with the number expected if the trend in 2000-07 had continued. Excesses of 680 suicides in Spain, 1,000 suicides in England and 4,750 suicides in the US have also been found in studies assessing the impact of economic recessions on suicide over the years 2008-10 (Lopez Bernal et al. 2013; Reeves et al. 2012). Tapia-Granados and Rodriguez (2015) obtain a similar result for Greece (but not for Finland and Iceland). The empirical evidence suggests, however, that social protection programs can be modifiers of the recession-health relation (Stuckler et al. 2017). According to Dumitru and Constantin (2016), higher unemployment and higher suicide rates have been observed in EU countries, both before and during the crisis period of 2007-2012, but the adverse health impacts were greatest in states that joined the EU after 2004, where economic changes were most rapid and social protection was weak.

\section{VARIABLES AND DISCUSSION}

\subsection{Male and female suicide}

Suicide-related mortality rates are used in this study to account for the various factors influencing mental health and measure the effects of macroeconomic fluctuations on mental distress. We note, in connection with our choice of dependent variable, that risk and protective factors for suicide and suicidal behavior vary according to risk groups and across the life span (WHO 2014; Djernes; 2006; Sher 2006; Case - Paxon 2005). Consequently, the mortality data used in this study is for males and females under the age of 65 , who are more likely to be affected by changes in the economic environment, and for males and females that are 65 years of age and over, who rarely participate in the labor force and are less sensitive to changes in the economic environment. This proxy for human and social well-being, much to our dislike, is expected to misrepresent the true state of the population's mental health (Wittchen et al. 2011; Ruhm 2000). This is only too evident in Wasserman (2009), where suicides are described as the visible side of a more generalized mental health problem. According to Wasserman's account, for each suicide there are at least two non-fatal suicide attempts and 100 new cases of depression. But inadequate information on psychiatric morbidity data has limited, and will continue to limit, the research on economic downturns and mental health to the investigation of suicide. 


\subsection{Social expenditure and suicide-related mortality rates}

As with many of the studies on the economics of suicide, we also use these expenditures as a measure for the overall effort exerted by national governments at providing for the primary care of high-risk mental health patients, as well as improving the financial conditions of those in disadvantaged circumstances (Suhrcke - Stuckler 2012; WHO 2011; Stuckler et al. 2009; Hagquist et al. 2008). On this account, we disaggregate public social expenditures, as defined and collected by the Organization for Economic Cooperation and Development (OECD), into its social welfare and health components. Accordingly, we evaluate annual data on real (public) health expenditure (PHE) per capita and real (public) social welfare expenditure (SWE) per capita, by country, which includes expenditures on family support programs, old age pensions, survivor benefits, housing assistance, unemployment benefits, active labor market programs and support for people with disabilities. We note, in connection with our inclusion of the public health expenditure variable, that a more encompassing measure of mental health care services and facilities, such as the number of psychiatrists, mental health nurses, or psychiatry care beds per 100,000 inhabitants, is incomplete and/or unavailable. To account for lags in response, both variables are introduced in the regressions in one-period lagged form.

\subsection{Economic control variables and suicide-related mortality rates}

Recessions generally lead to higher rates of unemployment. This, in turn, has harmful consequences on both the physical and mental health of the unemployed, and on the health of those who remain in employment but face an increased risk of unemployment (Kim et al. 2013; Bargard et al. 2012; Bambra, 2010). A common thread in the literature on the health consequences of recessions is that unemployment itself leads to an increase in mental disorders such as depression and anxiety symptoms. The most consistent results relate to suicides (Stuckler et al. 2012; Tapia-Granados - Diez Roux 2009; Miller et al. 2009). There is also ample evidence that working-age men are at the highest risk for suicide following job loss (Alvaro-Meca et al. 2013; De Vogli et al. 2013; Giuntoli et al. 2011). However, this relationship appears to be context specific because the increase in suicides during economic downturns is smaller in countries where the social safety net covers both genders more equitably (Oksuzyan et al. 2014; Modrek et al. 2013; WHO 2011; Hagquist et al. 2008). Given the level of information about the process in question, unemployment rates and income are introduced in the analysis as a reliable measure of the state of the economy and as a form of accounting for the everyday experiences of those groups of society that are 
more exposed to labor market fluctuations (Corcoran - Arensman 2010; Stuckler 2009; Minoiu - Andrés 2008).

\subsection{Social and life-style control variables and suicide-related mortality rates}

There is a long history of research speculating that individual family economic shocks (such as job loss or the increased involvement of a female spouse in the labor force) increase the likelihood of family dissolution, which, in turn, increases the probability of suicide risk factors for newly-divorced and their family members (Amato - Beattie 2011; Doiron - Mendolia 2011; Stevenson - Wolfers 2006). Consequently, divorce rates are portrayed in most studies as being positively associated with suicide (see for example Agerbo et al. 2007; Rodriguez 2005). In this interaction, vulnerabilities seem to depend on both gender and age: males are twice as likely to commit suicide as females in case of a divorce, while youth-suicide is higher in children living with a divorced parent (Yamamura 2010; Donald et al. 2006). The remaining variables that are thought to have a direct impact on the aggregate suicide rates are introduced in the analysis to control for social and life-style factors. Using the idea put forward by Andrés (2005) with reference to Durkheim (1951) that societal suicide rates are influenced by social integration and social regulation, the fertility rate is included as an explanatory variable in the regression. Accordingly, the presence of children heightens an individual's ties to his or her family and to society, making it less likely for that person to commit suicide. Similarly, a role for alcohol has been claimed in many reports. While Stuckler et al. (2009) argue that becoming unemployed worsens alcoholrelated harm, a study by APA (2003) found alcohol to be present in almost half of all persons who die by suicide. Lending weight to these interactions, a number of reviews that explore the evidence for alcohol misuse and suicidal behavior conclude that both are highly associated, especially among young males (Norstrom et al. 2012; Walsh - Walsh 2011).

\section{EMPIRICAL STRATEGY AND FINDINGS}

\subsection{Data and sample characteristics}

To quantify the effect of economic fluctuations on suicide, age-standardized and age-specific suicide mortality rates (SDR) per 100,000 individuals were taken from the WHO (2016) European Health for All database (HFA-DB), under the Disease Classification "Suicide and Self-Inflicted Injury", for each of the 15 
countries for which comparative data are available (Austria, Belgium, Denmark, Finland, France, Germany, Greece, Ireland, Italy, Luxembourg, Netherlands, Portugal, Spain Sweden, and the UK). This covers 1990-2013, although suiciderelated mortality data for Denmark, Greece and Italy were available up to only 2012. Social spending data in the domains of old age, survivors, incapacity related, health, family, active labor market programs, unemployment, housing, and other social policy areas, as defined in the panel, were extracted from the OECD Health Data 2016 edition, expressed in constant (2005) PPP\$ per capita. Data on the unemployment and income variables, by country and year, were obtained from the World Bank (2016) World Development Indicators Database and the WHO (2016) European Health for All database (HFA-DB), respectively. As a final consideration, the dataset for the crude divorce rate and the total fertility rate has been compiled from the Eurostat (2016) statistics database. To assist with the choice of methodology, Tables 1 and 2 provide some relevant statistics for the variables used in the estimation.

Table 1. Country-specific average suicide rates for EU15, 1990-2013.

\begin{tabular}{l|c|c|c|c|c}
\hline \hline$(1)$ & $(2)$ & $(3)$ & $(4)$ & $(5)$ & $(6)$ \\
& $S$ & $M S_{0-64}$ & $F S_{0-64}$ & $M S_{65+}$ & $F S_{65+}$ \\
\hline Austria & 17.88 & 23.50 & 7.27 & 73.08 & 18.99 \\
\hline Belgium & 18.14 & 24.41 & 9.04 & 51.04 & 16.10 \\
\hline Denmark & 14.66 & 18.36 & 7.31 & 43.96 & 19.06 \\
\hline Finland & 23.22 & 35.99 & 10.06 & 46.26 & 10.51 \\
\hline France & 17.24 & 22.85 & 8.02 & 57.55 & 16.42 \\
\hline Germany & 12.51 & 16.35 & 5.19 & 45.83 & 15.41 \\
\hline Greece & 3.09 & 4.49 & 1.03 & 10.12 & 2.27 \\
\hline Ireland & 11.45 & 18.35 & 4.56 & 16.15 & 4.18 \\
\hline Italy & 6.38 & 8.23 & 2.55 & 26.76 & 6.72 \\
\hline Luxembourg & 14.58 & 18.81 & 7.27 & 48.91 & 13.23 \\
\hline Netherlands & 9.07 & 11.38 & 5.47 & 21.63 & 9.32 \\
\hline Portugal & 7.11 & 8.68 & 2.56 & 37.38 & 8.52 \\
\hline Spain & 6.98 & 8.89 & 2.64 & 30.06 & 8.13 \\
\hline Sweden & 13.11 & 17.01 & 7.19 & 33.94 & 11.16 \\
\hline United Kingdom & 7.04 & 11.14 & 2.90 & 11.96 & 4.27 \\
\hline Source a & & & & &
\end{tabular}

Source: authors 
Table 2. Variables and general statistics $(\mathrm{N}=309)$

\begin{tabular}{|c|c|c|c|}
\hline Description & Notation & Mean & St. Dev. \\
\hline \multicolumn{4}{|l|}{ Dependent variables: } \\
\hline \multicolumn{4}{|l|}{$\begin{array}{l}\text { Age-standardized suicide mortality rates per 100,000 } \\
\text { inhabitants }\end{array}$} \\
\hline - All ages & $\mathrm{S}_{\mathrm{i}, \mathrm{t}}$ & 2.351547 & 0.511905 \\
\hline - Males $_{0-64}$ & MSO-64 & 2.663889 & 0.521874 \\
\hline - Females ${ }_{0-64}$ & FS0-64 & 1.515925 & 0.633584 \\
\hline - Males $_{65+}$ & MS65+ ${ }_{\mathrm{I}, \mathrm{t}}$ & 3.367698 & 0.652602 \\
\hline- Females $_{65+}$ & FS65+ ${ }_{\mathrm{I}, \mathrm{t}}^{1, \mathrm{t}}$ & 2.095788 & 0.743681 \\
\hline \multicolumn{4}{|l|}{ Independent variables: } \\
\hline $\begin{array}{l}\text { - Real per capita public expenditures on health - lagged } \\
\text { (at constant PPPs in } 2005 \text { US\$) }\end{array}$ & $\mathrm{PHE}_{\mathrm{t}-1}$ & 2169.620 & 805.7410 \\
\hline $\begin{array}{l}\text { - Real per capita public social welfare expenditures - } \\
\text { lagged (at constant PPPs in } 2005 \text { US\$) }\end{array}$ & $\mathrm{PSWE}_{\mathrm{t}-1}$ & 6364.506 & 2244.257 \\
\hline - Unemployment, total (\% of total labor force) & UEMP $_{\mathrm{t}-1}$ & 8.017781 & 4.135742 \\
\hline $\begin{array}{l}\text { - Gross Domestic Product per capita - lagged (at con- } \\
\text { stant PPPs in } 2005 \text { US\$) }\end{array}$ & $\mathrm{GDP}_{\mathrm{i}, \mathrm{t}-1}$ & 38046.36 & 13534.26 \\
\hline - Fertility rate, total (births per woman) & $\mathrm{TFR}_{\mathrm{it}}$ & 1.598462 & 0.234694 \\
\hline - Crude divorce rate (per 1,000 inhabitants) & $\operatorname{DIV}_{\mathrm{i}, \mathrm{t}}{ }^{1 \mathrm{t}}$ & 1.972189 & 0.727050 \\
\hline - Adult consumption of alcohol, per capita (liters) & $\mathrm{ALC}_{\mathrm{i}, \mathrm{t}}$ & 1.957485 & 0.703881 \\
\hline
\end{tabular}

Source: authors

\subsection{Model design and methodology}

In evaluating suicide mortality in the general population, or in specific age and sex groups, in relation to macroeconomic fluctuations in the European Union, the following model specification was followed:

$$
\begin{aligned}
\operatorname{lnSM}_{i t}=\alpha_{I} & +\beta_{1} P H E_{i t-1}+\beta_{2} P S W E_{i t-1}+\beta_{3} U E M P_{i t-1}+\beta_{4} G D P_{i t-1}+\beta_{5} T F R_{i t}+ \\
& +\beta_{6} D I V_{i t}+\beta_{f} A L C_{i t}+\beta_{8} \text { TREND }+\beta_{9} T R E N D^{2}+u_{i t}
\end{aligned}
$$

Equation (1) relates the natural log of suicide mortality to the per capita real public health and social welfare expenditure (PHE and PSWE), the unemployment rate (UEMP), the per capita real income (GDP), the total fertility rate (TFR), the divorce rate (DIV), per capita alcohol consumption (ALC), and a second order polynomial function of time (TREND and TREND ${ }^{2}$ ). While the $\alpha_{I}$ term is time invariant and captures country-specific effects that are not included in the model, the $u_{i t}$ is the observation-specific error term. Finally, the subscript $i$ and $t$ represent countries and time periods, respectively, for which comparative data are available, and $t-1$ represents the one-period lagged explanatory variables which are included 
explicitly in the model specifications. The underlying cross-sectional data set was an unbalanced panel data set with approximately 311 observations. Regressions were performed by means of the statistical software EViews (version 9.0).

This analysis makes use of a fixed effects (or within) transformation of the data through which omitted country-level time-invariant characteristics may be fully captured and corrections are made on several important problems associated with the use of this type of econometric procedure for purposes of pooling (Gujarati and Porter 2008). First, we include a Cochrane-Orcutt (1949) iterative procedure in our specifications to correct for correlation within and between panels, and White's (1980) method for obtaining heteroscedasticity-consistent estimations. Second, as suggested by Lichtenberg (2004), economic and policy variables are included in the regressions in one-period lagged form. This is justified by the need to account for lags in response to changes in given economic and policy variables, and the need to ensure that we are measuring the effect of expenditures on suicide mortality rather than the effect of suicide mortality on expenditures. Lastly, panel unit root tests developed by Levin, Lin, and Chu (2002) are used to ensure that the variables included in all specifications are free of any unit root processes. Except for the divorce rate, the test results indicate that there is insufficient evidence pointing to the acceptance of the (null) hypothesis that all series in the panel are non-stationary and that the series have been generated by stationary or approximately stationary processes.

\subsection{Estimation results}

Tables 3 and 4 summarize our results (with standard errors in parenthesis below each coefficient) in models that have been repeatedly used, following Hamermesh and Soss (1974), to estimate the effect of macroeconomic fluctuations on total, male and female ( 0 to 64 years of age and 65 years of age and older) suicide mortality. For now, however, it is instructive to examine the complete regression output in Models 1, 2, and 3 (Table 3) carefully, each corresponding to a different dependent variable (total, male, and female suicide mortality rates). While the results are generally good (significant $t$ values, $\mathrm{R}^{2} \mathrm{~s}$ of around 0.95 and standard errors of the regressions that are less than 5 percent of the dependent variable means), the empirical evidence suggests that some of the explanatory variables of interest do not have the expected signs and do not significantly influence suicide mortality rates (e.g., ALC, TFR, and PHE). For example, the coefficient estimates for the impact of public health expenditures are positive but only statistically significant at the 11 to 30 level in the models for total and male suicide rates (Models 1 and 2). For females (Model 3), the effect is negative but only significant at the 80 percent level. These results were subsequently endorsed by regressions that 
Table 3. Effects estimates of age-standardized total suicide mortality equations

\begin{tabular}{|c|c|c|c|}
\hline & Model 1 & Model 2 & Model 3 \\
\hline Dep. variables & $\ln S$ & $\operatorname{lnMS}$ & $\operatorname{lnFS}$ \\
\hline \multicolumn{4}{|l|}{ Indep. variables } \\
\hline Constant & $\begin{array}{r}3.017210^{*} \\
(0.281390) \\
\end{array}$ & $\begin{array}{r}3.423714^{*} \\
(0.336302) \\
\end{array}$ & $\begin{array}{r}2.112699 * \\
(0.373633) \\
\end{array}$ \\
\hline PHE(-1) & $\begin{array}{r}0.0000734 \\
(0.000083) \\
\end{array}$ & $\begin{array}{c}0.000166 \\
(0.000104) \\
\end{array}$ & $\begin{array}{l}-0.0000119 \\
(0.0000836) \\
\end{array}$ \\
\hline PSWE(-1) & $\begin{array}{l}-0.0000776^{* *} \\
(0.000041) \\
\end{array}$ & $\begin{array}{c}-0.000104 * * \\
(0.0000502) \\
\end{array}$ & $\begin{array}{r}-0.0000882 * \\
(0.0000265) \\
\end{array}$ \\
\hline UEMP(-1) & $\begin{array}{l}0.009753^{* * *} \\
(0.005643)\end{array}$ & $\begin{array}{c}0.013030 * * \\
(0.005800)\end{array}$ & $\begin{array}{r}0.012241 * \\
(0.005220)\end{array}$ \\
\hline GDP(-1) & $\begin{array}{c}-0.0000151^{* * *} \\
(0.0000086)\end{array}$ & $\begin{array}{c}-0.0000177^{*} \\
(0.00000626) \\
\end{array}$ & $\begin{array}{l}-0.000003 \\
(0.0000129) \\
\end{array}$ \\
\hline TFR & $\begin{array}{c}-0.048938 \\
(0.109041) \\
\end{array}$ & $\begin{array}{c}-0.015584 \\
(0.114651) \\
\end{array}$ & $\begin{array}{c}-0.067272 \\
(0.157063) \\
\end{array}$ \\
\hline$\overline{\text { DIV }}$ & $\begin{array}{c}0.085975^{* *} \\
(0.042251) \\
\end{array}$ & $\begin{array}{c}0.091485 * * \\
(0.043832) \\
\end{array}$ & $\begin{array}{r}0.107620^{*} \\
(0.040607) \\
\end{array}$ \\
\hline ALC & $\begin{array}{c}-0.002052 \\
(0.023701) \\
\end{array}$ & $\begin{array}{c}-0.002031 \\
(0.022875) \\
\end{array}$ & $\begin{array}{c}0.010507 \\
(0.034058) \\
\end{array}$ \\
\hline TREND & $\begin{array}{c}0.005084 \\
(0.012272) \\
\end{array}$ & $\begin{array}{c}0.009705 \\
(0.012660) \\
\end{array}$ & $\begin{array}{c}-0.024507 \\
(0.015653)\end{array}$ \\
\hline TREND $^{2}$ & $\begin{array}{c}-0.000129 \\
(0.000338) \\
\end{array}$ & $\begin{array}{c}-0.000362 \\
(0.000433) \\
\end{array}$ & $\begin{array}{c}0.000734 \\
(0.000510)\end{array}$ \\
\hline $\mathrm{AR}(1)$ & $\begin{array}{r}0.648837^{*} \\
(0.074284)\end{array}$ & $\begin{array}{c}0.618581 * \\
(0.068851)\end{array}$ & $\begin{array}{r}0.372640 * \\
(0.089801)\end{array}$ \\
\hline $\mathrm{R}^{2}$ & 0.972549 & 0.966392 & 0.944837 \\
\hline Adjusted $\mathrm{R}^{2}$ & 0.970246 & 0.963572 & 0.940207 \\
\hline S.E. of regression & 0.087672 & 0.093598 & 0.147768 \\
\hline DW statistic & 2.145448 & 1.966252 & 2.169657 \\
\hline F statistic & 422.1918* & 342.6603* & 204.1079* \\
\hline Type of panel & Unbalanced & Unbalanced & Unbalanced \\
\hline Observations & 311 & 311 & 311 \\
\hline Cross-sections & 15 & 15 & 15 \\
\hline Period & 1990-2013 & 1990-2013 & 1990-2013 \\
\hline
\end{tabular}

Note: $*, * *, * * *$ denotes significance at $1 \%, 5 \%, 10 \%$, respectively.

Source: authors

disaggregate male and female suicide rates across age categories and coincide with previous panel data studies on the health consequences of economic downturns internationally (Modrek et al. 2013; Stuckler et al. 2010).

However, other factors have the expected sign and do significantly influence total and gender-specific suicide mortality rates. For example, since all regression coefficients are interpreted as semi-elasticities, every additional percentage point 
increase in unemployment is associated with a 0.9 to a 1.3 percent increase in total, male and female suicide mortality rates in the following year. In the same way, divorce rates are consistently associated with higher suicide rates in all regressions. Furthermore, this influence appears to be more pronounced among women and appears to be the single significant sociological control variable in the model explaining female suicide rates (Model 3). As suggested by Minoiu and Andrés (2008), the significantly positive relation between these two variables might reflect the effect of an omitted variable, such as stress level, which plays a very important role in the determination of female suicidal behavior and is positively correlated with both divorce rates and suicide rates. As a result, an additional divorce (per 1,000 persons) is associated with a 10 percent increase in female suicide rates and an 8.6 to a 9.1 percent increase in the models for total and male suicide rates (Models 1 and 2). On the other hand, increases in real GDP per capita are significantly associated with a reduction in suicide rates among males and appears to drive the results for total suicide rates (Model 1). This coefficient is negative but statistically insignificant in the model for female suicide rates (Model 3). This finding enhances the coherency of the literature and strengthens the argument that male suicide behavior could be more responsive to unfavorable economic conditions, as opposed to female behavior. More importantly, the coefficients on the government involvement in social protection programs are negative and statistically significant in all regressions (Models 1, 2, and 3). Hence, a $\$ 100$ rise in real social welfare expenditures $\left(\mathrm{PSWE}_{\mathrm{t}-1}\right)$ per capita causes a 0.776 to a 1.04 percent drop in total, male and female suicide mortality in the following year. It is worth noting, however, that these magnitudes are higher for male suicide rates than for female (and total) suicide rates and is consistent with evidence that in countries where social welfare programs cover both genders more equitably, such as in Finland and Sweden, the increase in male suicides during economic downturns is smaller (WHO 2011; Hagquist et al. 2008). Final points worth noting concern the possibility that country-specific influences other than those explicitly included in our specifications may have an impact on suicide mortality rates. The estimated coefficients on the constant term are positive and statistically significant in all regressions in Tables 3 and 4.

In order to bring this macro-level study closer in line with micro-level ones, models in Table 4 use age-adjusted, male and female suicide mortality rates as dependent variables. We note, in connection with these results, that our models explain male suicide rates better than female rates and rates in the 0-64 age groups better than those in the 65 and older age groups. For males, the explanatory power of the regression is relatively high in the $0-64$ age group but comparatively lower for the 65 and older age group. Not surprisingly, the coefficient estimates for younger males appear to drive the results for total suicide rates (Model 4, 
Table 4). This is illustrative of the relatively constant predominance of suicide rates in males over suicide rates in females (males account for the largest share of suicide acts, as illustrated by the 3.0 to 3.9 male/female ratio of age-standardized European suicide rates), and the fact that currently more young people than elderly people are dying from suicide (WHO 2014).

Table 4. Fixed effects estimates of age-standardized suicide mortality equations

\begin{tabular}{|c|c|c|c|c|}
\hline & Model 4 & Model 5 & Model 6 & Model 7 \\
\hline Dep. variables & $\operatorname{lnMS}_{0-64}$ & $\operatorname{lnFS} S_{0-64}$ & $\operatorname{lnMS}_{65^{+}}$ & $\operatorname{lnFS}_{65+}$ \\
\hline \multicolumn{5}{|l|}{ Indep. variables } \\
\hline Constant & $\begin{array}{c}3.369524 * \\
(0.387331)\end{array}$ & $\begin{array}{c}2.032113 * \\
(0.418402)\end{array}$ & $\begin{array}{c}3.678320 * \\
(0.334682)\end{array}$ & $\begin{array}{c}2.931984 * \\
(0.592183)\end{array}$ \\
\hline PHE(-1) & $\begin{array}{c}0.000195 \\
(0.000122)\end{array}$ & $\begin{array}{c}0.0000464 \\
(0.0000729)\end{array}$ & $\begin{array}{c}0.0000624 \\
(0.0000734)\end{array}$ & $\begin{array}{c}-0.000202 \\
(0.000128)\end{array}$ \\
\hline PSWE(-1) & $\begin{array}{c}-0.000112^{* *} \\
(0.0000591) \\
\end{array}$ & $\begin{array}{c}-0.0000701 * \\
(0.0000277)\end{array}$ & $\begin{array}{l}-0.0000456 * * * \\
(0.000027)\end{array}$ & $\begin{array}{c}-0.000139 * \\
(0.0000426)\end{array}$ \\
\hline UEMP(-1) & $\begin{array}{c}0.013949 * * \\
(0.006754)\end{array}$ & $\begin{array}{l}0.011508^{* * *} \\
(0.006234)\end{array}$ & $\begin{array}{r}0.013484 * \\
(0.004632) \\
\end{array}$ & $\begin{array}{c}0.015669 * * \\
(0.006763) \\
\end{array}$ \\
\hline GDP(-1) & $\begin{array}{c}-0.0000195 * \\
(0.00000652) \\
\end{array}$ & $\begin{array}{c}-0.0000112 \\
(0.0000128)\end{array}$ & $\begin{array}{c}-0.00000886 \\
(0.00000762) \\
\end{array}$ & $\begin{array}{c}0.000025^{*} \\
(0.0000927) \\
\end{array}$ \\
\hline TFR & $\begin{array}{c}-0.069073 \\
(0.123308)\end{array}$ & $\begin{array}{c}0.002461 \\
(0.175952)\end{array}$ & $\begin{array}{c}0.057769 \\
(0.125186)\end{array}$ & $\begin{array}{c}-0.401703^{* *} \\
(0.197501)\end{array}$ \\
\hline DIV & $\begin{array}{r}0.116041^{*} \\
(0.040165)\end{array}$ & $\begin{array}{c}0.102594 * * \\
(0.045553)\end{array}$ & $\begin{array}{c}0.061123 \\
(0.046699)\end{array}$ & $\begin{array}{c}0.175730^{*} \\
(0.052599)\end{array}$ \\
\hline ALC & $\begin{array}{c}-0.012329 \\
(0.029924)\end{array}$ & $\begin{array}{c}-0.004303 \\
(0.042653)\end{array}$ & $\begin{array}{c}0.026377 \\
(0.031019)\end{array}$ & $\begin{array}{c}0.054666 \\
(0.042346)\end{array}$ \\
\hline TREND & $\begin{array}{c}0.011568 \\
(0.014082)\end{array}$ & $\begin{array}{c}-0.010585 \\
(0.017251)\end{array}$ & $\begin{array}{l}-0.011461 \\
(0.010784)\end{array}$ & $\begin{array}{c}-0.067825 * \\
(0.014235)\end{array}$ \\
\hline TREND $^{2}$ & $\begin{array}{l}-0.000360 \\
() 0.000547)\end{array}$ & $\begin{array}{c}0.000312 \\
(0.000531) \\
\end{array}$ & $\begin{array}{c}-0.000114 \\
(0.000392) \\
\end{array}$ & $\begin{array}{c}0.002267 * \\
(0.000535) \\
\end{array}$ \\
\hline $\operatorname{AR}(1)$ & $\begin{array}{r}0.580055^{*} \\
(0.082331) \\
\end{array}$ & $\begin{array}{c}0.421062 \\
(0.085405) \\
\end{array}$ & $\begin{array}{c}0.417892 * \\
(0.063257) \\
\end{array}$ & $\begin{array}{c}-0.131358^{*} \\
(0.145771) \\
\end{array}$ \\
\hline $\mathrm{R}^{2}$ & 0.959310 & 0.943306 & 0.957763 & 0.815684 \\
\hline $\mathrm{AdjR}^{2}$ & 0.955896 & 0.938549 & 0.954219 & 0.800216 \\
\hline S.E. of regression & 0.107975 & 0.155615 & 0.120762 & 0.308642 \\
\hline DW Statistic & 1.959902 & 2.112803 & 2.030508 & 2.042672 \\
\hline F Statistic & 280.9486* & $198.2775^{*}$ & $270.2213 *$ & 52.73663* \\
\hline Type of Panel & \multicolumn{2}{|c|}{ Unbalanced } & \multicolumn{2}{|c|}{ Unbalanced } \\
\hline Observations & \multicolumn{2}{|c|}{311} & \multicolumn{2}{|c|}{311} \\
\hline Cross-sections & \multicolumn{2}{|c|}{15} & \multicolumn{2}{|c|}{15} \\
\hline Period & \multicolumn{2}{|c|}{ 1990-2013 } & \multicolumn{2}{|c|}{ 1990-2013 } \\
\hline
\end{tabular}

Note: *,**, *** denotes significance at $1 \%, 5 \%, 10 \%$, respectively.

Source: authors 
In comparisons of younger and older populations, the results depicted in Models 4 through 7 (Table 4) indicate that the unemployment rate is the single economic control variable which is significantly associated with suicide rates (in all regressions and for all age groups). On the other hand, the link between real GDP per capita and suicide rates varies widely across different population groups. As Table 4 indicates, among the 0-64 age group, only among males (Model 4) do we find that lower levels of income per capita are significantly associated with higher suicide rates. For women in this age category and as hypothesized earlier, the effect is negative but statistically insignificant, and seems to indicate that younger female suicide behavior, as opposed to younger male behavior, is more dependent on the availability of jobs and job stability than on the level of earnings generated from those same jobs (Modrek et al. 2013; Friedland - Price 2003). This explanation loses ground, however, for women aged 65 years old and above, since the estimated coefficient is positive and significant in the model for elderly female suicide rates (Model 7). This finding might reflect the fact that the proportion of elderly individuals who are poor is substantially higher among widowed women, most of whom, as a result of financial distress, may decide to remain in or join the labor force against their preferences (US Census Bureau 2003). This may in turn increase the level of stress and insecurity and place an upward pressure on the suicide rates of this demographic group.

In describing our findings for the public policy variables, it is worth noting that higher levels of expenditure per capita are associated with lower suicide rates in all regressions. Specifically, public social welfare expenditures are consistently significant in all regressions. Our estimates suggest that a $\$ 100$ rise in real public social welfare expenditures $\left(\mathrm{PSWE}_{\mathrm{t}-1}\right.$ ) per capita in a given year causes a 0.456 to 1.39 percent decrease in suicide mortality rates in the following year (Models 4 through 7). Furthermore, the levels of significance are higher for female suicide rates than for male suicide rates. In a similar vein, increased public health expenditures also lead to lower suicide rates. However, the lack of explanatory power for this regressor lends no support for the point of view that governments can effectively manage mental illness prevention and mental health promotion, at least for this particular sample of EU countries.

As for other determinants of age and gender-specific suicide, divorce and higher suicide rates are associated since the estimated coefficient on the divorce variable is positive and statistically significant in all regressions. The positive relation between these two variables may confirm that separation is thought to reduce family ties and social integration while increasing the likelihood of depression, emotional, and economic hardship, all of which are considered to be significant risk factors (Minoiu - Andrés 2008), especially among men (Andrés 2005). In addition, higher fertility in a given year is associated with lower suicide 
rates but only among elderly women (Model 7). The inverse relation between these two variables might suggest that larger families are more effective at producing home care for the elderly or that both types of human capital investment, family size and mental health, are complementary. However, the empirical evidence on the success of advances in knowledge and technology that may be used to prepare individuals to face potential distressing life changes - in adolescence, parenthood, middle age, and old age - is inconclusive. We note that only among elderly females (Model 7) do we find that suicides significantly decrease over time at an increasing rate. Finally, the effect of alcohol consumption on suicide rates appears to be zero in our estimations, which is, however, inconsistent with some evidence in the literature suggesting a problematic abuse of this substance among, for example, older adults (Kuerbis et al. 2014).

\section{DISCUSSION AND CONCLUDING REMARKS}

Globally, suicides account for nearly half of all violent deaths in men and nearly three quarters in women. In view of attempts that are never reported and selfinflicted deaths that are officially certified as having resulted from causes other than suicide, experts estimate that the true dimension of this public health problem is even more serious than official figures indicate. In this study, we provide an evidence-based account on this public health issue and make response suggestions based on empirical evidence on the relation between the socioeconomic determinants of crisis and suicide mortality using data for fifteen EU countries over the period 1990 and 2013. Because this dimension of mental health may be affected by a variety of mechanisms that have heterogeneous impacts across segments of the population, we assess the contribution of these variables to explain suicide rates for total, males and females in two age groups, from 0-64 years to 65 and over, using a fixed-effects estimation strategy.

Our findings support the hypothesis that lower income, rising unemployment, and higher divorce rates have led to increased suicide mortality among males and females of all ages. More importantly, the empirical results show that public social welfare expenditures (PSWE) matters more than public health expenditures (PHE) when evaluated either in terms of coefficient size or statistical significance. While the social welfare expenditures term is negative and statistically significant in all regressions, the statistically insignificant negative results on the public health expenditure term suggest that many public health systems and services fail to provide timely and effective help to people most in need of assistance. Overall, our study further contributes to the health economics literature by showing that the suicide rate would have climbed higher in the most recent recession in the 
EU had it not been for the substantial buffering effects of social protection programs on mental health, especially among working-age males and females and their children, and that these populations should be targeted during the worst of times or integrated into safety net programs before the next economic downturn. It is possible, however, that several risk factors may be missing or inadequately studied in our analysis, thus preventing a full and realistic understanding of this phenomenon.

\section{REFERENCES}

Agerbo, E. - Sterne, S. - Gunnel, J. (2007): Combining Individual Level and Ecological Data to Determine Compositional and Contextual Socio-Economic Risk Factors of Suicide. Social Science \& Medicine 64(2): 451-461.

Alvaro-Meca, A. - Kneib, T. - Gil-Prieto, R. - Gil de Miguel, A. (2013): Epidemiology of Suicide in Spain, 1981-2008: A Spatiotemporal Analysis. Public Health 127(4): 380-385.

Amato, P. R. - Beattie, B. (2011): Does the Unemployment Rate Affect the Divorce Rate? An Analysis of State Data, 1960-2005. Social Science Research 40(3): 705-715.

American Psychiatric Association (2003): Practice Guidelines for the Assessment and Treatment of Patients with Suicidal Behaviors. American Journal of Psychiatry 160: 1-50.

Anderson, P. (2011): Economic Crisis and Mental Health and Wellbeing. Background Paper for the WHO/Euro "Impact of the Economic Crisis on Mental Health" Project, Maastricht University.

Apter, A. (2010): Clinical Aspects of Suicidal Behavior Relevant to Genetics. European Psychiatry 25(5): 257-259.

Asteriou, D. - Hall, S. (2007): Applied Econometrics: A Modern Approach. New York: Palgrave MacMillan.

Bambra, C. (2010): Yesterday Once More? Unemployment and Health in the 21st Century. Journal of Epidemiology and Community Health 64(3): 213-215.

Burgard, S. - Kalousova, L. - Seefeldt, K. (2012): Perceived Job Insecurity and Health: The Michigan Recession and Recovery Study. Journal of Occupational and Environmental Medicine 54(9): 1101-1106.

Beautrais, A. (2006): Suicide in Asia. Crisis 27(2): 55-57.

Beautrais, A. - Collings, S. - Ehrhardt, P. (2005): Suicide Prevention: A Review of Evidence of Risk and Protective Factors, and Points of Effective Intervention. Wellington: Ministry of Health.

Case, A. - Paxon, C. (2005): Sex Differences in Morbidity and Mortality. Demography 42(2): 189-214.

Chang, S. - Stuckler, D. - Yip. P. - Gunnell, D. (2013): Impact of 2008 Global Economic Crisis on Suicide: Time Trend Study in 54 Countries. British Medical Journal 347: f5239.

Chang, S. - Gunnell, D. - Stern, J. - Lu, T. - Cheng, A. (2009): Was the Economic Crisis of 19971998 Responsible for Rising Suicide Rates in East/Southeast Asia? A Time-Trend Analysis for Japan, Hong Kong, South Korea, Taiwan, Singapore, and Thailand. Social Science \& Medicine 68(7): 1322-1331.

Christodoulou, N. - Christodoulou, G. (2013): Financial Crises: Impact on Mental Health and Suggested Responses. Psychotherapy and Psychosomatics 82(5): 279-284. 
Cochrane, D. - Orcutt, G. (1949): Applications of Least Squares Regressions to Relationships Containing Autocorrelated Error Terms. Journal of the American Statistical Association 44(245): 32-61.

Corcoran, P. - Griffin, E. - Arensman, E. - Fitzgerald, A. - Perry, E. (2015): Impact of the Economic Recession and Subsequent Austerity on Suicide and Self-Harm in Ireland: An Interrupted Time Series Analysis. International Journal of Epidemiology 44(3): 969-977.

Corcoron, P. - Arensman, E. (2010): Explaining the Rise in Youth Suicide. NBER Working Paper 7713.

De Vogli, R. - Marmot, M. - Stuckler, D. (2013): Excess Suicides and Attempted Suicides in Italy Attributable to the Great Recession. Journal of Epidemiology and Community Health 67(4): 378-379.

Djernes, J. (2006): Prevalance and Predictors of Depressions in Populations of Elderly: A Review. Acta Psychiatrica Scandinavica 113(5): 372-387.

Doiren, D. - Mendolia, S. (2011): The Impact of Job Loss in Family Dissolution. Journal of Population Economics 25(1): 367-398.

Donald, M. - Dower, J. - Correa-Velez, I. - Jones, M. (2006): Risk and Protective Factors for Medically Serious Suicide Attempts: A Comparison of Hospital-Based with Population-Based Samples of Young Adults. Australian and New Zealand Journal of Psychiatry 40(1): 87-96.

dos Santos, J. - Tavares, M. - Barros, P. (2016): More than Just Numbers: Suicide Rates and the Economic Cycle in Portugal (1910-2013). SSM - Population Health 2: 14-23.

Dumitru, M. - Constantin, B. (2016): The Effects of the Last Global Economic Crisis on the Suicide Rate in Europe. European Psychiatry 33: S112-S113.

Durkheim, E. (1897/1951): Suicide. Reprinted Elencoe, III. Free Press.

Economou, M. - Madianos, M. - Peppou, L. - Patelakis, A. - Stefanis, C. (2013): Major Depression in the Era of Economic Crisis: A Replication of a Cross-Sectional Study across Greece. Journal of Affective Disorders 145(3): 308-314.

Eurostat (2016): Social Protection Statistics - Statistics Explained. http://ec.europa.eu/eurostat/ statistics-explained/index.php/Population_and_social_conditions, accessed 02/04/2016.

Friedland, D. - Richard, H. (2003): Underemployment: Consequences for the Health and WellBeing of Workers. American Journal of Community Psychology 32(1-2): 33-45.

Galfalvy, H. - Currier, D. - Oquendo, M. - Sullivan, G. - Huang, Y. - Mann, J. (2009): Lower CSF MHPG Predicts Short-Term Risk for Suicide Attempt. International Journal of Neuropsychopharmacology 12: 1327-1335.

Garcy, A. - Vagero, D. (2013): Unemployment and Suicide during and after a Deep Recession: A Longitudinal Study of 3.4 Million Swedish Men and Women. American Journal of Public Health 103(6): 1031-1038.

Gerdtham, U. - Ruhm, C. (2006): Deaths Rise in Good Times: Evidence from OECD. Economics and Human Biology 4(3): 298-316.

Giuntoli, G. - South, J. - Kinsella, K. - Karban, K. (2011): Mental Health, Resilience and the Recession in Bradford. York: JRF.

Glonti, K. - Gordeev, V. - Goryakin, Y. - Reeves, A. - Stuckler, D. - McKee, M. - Roberts, B. (2015): A Systematic Review on Health Resilience to Economic Crises. PLoS ONE 10(4): e0123117.

Gujarati, D. - Porter, D. (2008): Basic Econometrics. New York: McGraw-Hill.

Gvion, Y. - Apter, A. (2012): Suicide and Suicidal Behavior. Public Health Reviews 34(2): 1-20.

Hagquist, C. - Silburn, S. - Zurbrick, S. - Lindberg, G. - Ringbäck, W. G. (2008): Suicide and Mental Health Problems among Swedish Youth in the Wake of the 1990s Recession. International Journal of Social Welfare 9(3): 211-219. 
Hamermesh, D. - Soss, N. (1974): An Economic Theory of Suicide. Southern Economic Journal 41: 188-199.

Hegerl, U. - Wittenburg, L., et al. (2009): Optimizing Suicide Prevention Programs and their Implementation in Europe (OSPI Europe): A Evidence Based Multi-Level Approach. BMC Public Health 9: 428-436.

Karanikolos, M. - Mladovsky, P. - Cylus, J. - Thomson, S. - Basu, S. - Stuckler, D. - Mackenbach, J. - McKee, M. (2013): Financial Crisis, Austerity, and Health in Europe. The Lancet 381(9874): 1323-1331.

Khang, Y. - Lynch, W. (2005): Impact of Economic Crisis on Cause-Specific Mortality in South Korea. International Journal of Epidemiology 34(6): 1291-1301.

Kim, J. - Son, N. - Park, E. - Nam, C. - Kim, T. - Cho, W. (2013): The Relationship between Changes in Employment Status and Mortality Risk Based on the Korea Labor and Income Panel Study (2003-2008). Asia Pacific Journal of Public Health 27(2): NP993-NP1001.

Kuerbis, A. - Sacco, P. - Blazer, D. - Moore, A. (2014): Substance Abuse among Older Adults. Clinical Geriatric Medicine 30(3): 629-654.

Latif, E. (2015): The Impact of Economic Downturn on Mental Health in Canada. International Journal of Social Economics 42(1): 33-46.

Levin, A. - Lin, C. - Chu, C. (2002): Unit Root Tests in Panel Data: Asymptotic and Finite Sample Properties. Journal of Econometrics 108(1): 1-24.

Lichtenberg, F. (2004): Sources of US longevity Increase, 1960-2001. The Quarterly Review of Economics and Finance 44(3): 369-389.

Lopez, B. J. - Gasparrini, A. - Artundo, C. - McKee, M. (2013): The Effect of the Late 2000s Financial Crisis on Suicides in Spain: An Interrupted Time-Series Analysis. European Journal of Public Health 23(5): 732-736.

Lucey, S. - Corcoron, P. - Keeley, H. - Brophy, J. - Arensman, E. - Perry, I. (2005): Socioeconomic Change and Suicide: A Time-Series Study from the Republic of Ireland. Crisis 26(2): 90-94.

Mann, J. - Currier, D. (2010): Stress, Genetics and Epigenetic Effects of the Neurobiology of Suicidal Behavior and Depression. European Psychiatry 25(5): 268-271.

Martin-Carrasco, M. (2015): Economic Crises and Mental Health Planning in Europe. European Psychiatry 30(1): 103.

McDaid, D. - Kennely, B. (2009): An Economic Perspective on Suicide across Five Continents. Oxford Textbook of Suicidiology and Suicide Prevention: A Global Perspective. Oxford: Oxford University Press.

Miller, D. - Page, M. - Stevens, A. - Filipski, M. (2009): Why are Recessions Good for Your Health? American Economic Review 99(2): 122-127.

Minoiu, C. - Andrés, A. (2008): The Effect of Public Spending on Suicide: Evidence from US State Data. The Journal of Socio-Economics 37(1): 237-261.

Modrek, S. - Stuckler, D. - McKee, M. - Cullen, M. - Basu, S. (2013): A Review of Health Consequences of Recessions Internationally and a Synthesis of the US Response during the Great Recession. Public Health Review 35(10): 1.

Morselli, H. (1881): Suicide: An Essay on Comparative Moral Statistics. London: C. Kegan Paul.

Nock, M. - Borges, G. - Bronet, E. - Kessler, R. - Lee, S. (2008). Suicide and Suicidal Behavior. Epidemiological Review 30: 133-154.

Norstrom, T. - Stuckler, A. - Schibuya, K. (2011): The Importance of Alcohol Beverage Type for Suicide in Japan: A Time-Series Analysis, 1963-2007. Drug and Alcohol Review 31(3): 251-256.

OECD (2016): OECD.Stat. http://dx.doi.org/10.1787/data-00285-en, accessed 07/03/2015. 
Oksuzyan, A. - Shkolnikova, M. - Vaupel, J. - Christensen, K. - Shkolnikov, V. (2014): Sex Differences in Health and Mortality in Moscow and Denmark. European Journal of Epidemiology 29(4): 243-252.

Oyesanya, M. - Lopez-Morinigo, J. - Dutta, R. (2015): Systematic Review of Suicide in Economic Recession. World Journal of Psychiatry 5(2): 243-254.

Read, J. (2010): Can Poverty Drive You Mad? Schizophrenia, Socio-Economic Status and the Case of Primary Prevention. New Zealand Journal of Psychology 39(2): 7-19.

Reeves, A. - Stuckler, D. - McKee, M. - Gunnell, D. - Chang, S. - Basu, S. (2012): Increase in State Suicide Rates in the USA. during Economic Recession. Lancet 380(9856): 1813-1814.

Rodriguez, A. (2005): Income Inequality, Unemployment and Suicide: A Panel-Data Analysis of 15 European Countries. Applied Economics 37: 439-451.

Ruhm, C. (2000): Are Recessions Good for Your Health? Quarterly Journal of Economics 115(2): 617-650.

Ruhm, C. (2015): Recessions, Healthy No More? Journal of Health Economics 42: 17-28.

Sareen, J. - Afifi, T. - McMillan, K. - Asmendson, G. (2011): Relationship between Household Income and Mental Disorders: Findings from a Population-Based Longitudinal Study. Archive of General Psychiatry 68(4): 419-427.

Sher, L. (2006): Per Capita Income is Related to Suicide in Men but Not in Women. Journal of Men's Health and Gender 3(1): 39-42.

Skouras, T. (2013): The Euro Crisis and Its Lessons from a Greek Perspective. Society and Economy 35(1): 51-69.

Stack, S. (1989): The Impact of Divorce on Suicide in Norway, 1951-1980. Journal of Marriage and Family 51(1): 229-238.

Stevenson, D. - Wolfers, J. (2006): Bargaining in the Shadow of the Law: Divorce Law and Family Distress. Quarterly Journal of Economics 121: 267-288.

Stuckler, D. - Basu, S. - Suhrcke, M. (2010): Responding to the Economic Crisis: A Primer for Public Health Professionals. Journal of Public Health Policy 32(3): 298-306.

Stuckler, D. - Basu, S. - Suhrcke, M. (2011): Effects of the 2008 Recession on Health: A First Look at European Data. Lancet 378(9786): 124-125.

Stuckler, D. - King, L. - McKee, M. (2009): Mass Privatization and the Post-Communist Mortality Crisis. Lancet 373: 399-407.

Stuckler, D. - Meissner, C. - Fishback, P. - Basu, S. - McKee, M. (2012): Banking Crises and Mortality during the Great Depression: Evidence from US Urban Populations, 1929-1937. Journal of Epidemiology and Community Health 66: 410-419.

Stuckler, D. - Reeves, A. - Loopstra, R. - Karanikolos, M. - McKee, M. (2017): Austerity and Health: The Impact in the UK and Europe. European Journal of Public Health 27(S4): 18-21.

Suhrcke, M. - Stuckler, D. (2012): Will the Recession be Bad for Our Health? It Depends. Social Science \& Medicine 74(5):s 647-653.

Tapia-Granados, J. - Rodriguez, J. (2015): Health, Economic Crises, and Austerity: A Comparison of Greece, Finland and Iceland. Health Policy 119(7): 941-953.

Tapia-Granados, S. - Diez Roux, A. (2009): Life and Death during the Great Depression. Proceedings of the National Academy of Science of the United States of America 106(41): 17290 17295.

The World Bank (2015): World Development Indicators. http://data.worldbank.org/news/releaseof-world-development-indicators-2015, accessed 07/03/2015.

US Census Bureau (2003): Selected Characteristics of People 15 Years and Over by Total Money Income in 2002, Work Experience in 2002, Race, Hispanic Origin, and Sex. Washington, DC: US Government Printing Office. 
US Public Health Service (1999): The Surgeon General's Call to Action to Prevent Suicide. Washington, D.C.

Walsh, B. - Walsh, D. (2011): Suicide in Ireland: The Influence of Alcohol and Unemployment. The Economic and Social Review 42(1): 27-47.

Wasserman, D. (2009): Mental Health and Suicidal Behavior in Times of Economic Crisis: Impact and Prevention. In: Mental Health and Suicidal Behavior in Times of Economic Crisis. Stockholm, Sweden.

White, H. (1980): A Heteroscedasticity-Consistent Covariance Matrix Estimator and a Direct Test for Heteroscedasticity. Econometrica 48(4): 817-838.

WHO Regional Office for Europe (2016): WHO European Health for All Databases. http://data. euro.who.int/hfadb/, accessed 07/03/2016.

Wittchen, H. - Jacobi, F. - Rehm, J. - Gustavsson, A. - Svensson, M. - Jonsson, B. (2011): The Size and Burden of Mental Disorders and Other Disorders of the Brain in Europe, 2010. European Neuropsychopharmacology 21(8): 655-679.

World Health Organization (2014): Preventing Suicide: A Global Imperative. http://www.who.int/ mental_health/suicide-prevention/world_report_2014/en/, accessed 09/04/2014.

World Health Organization (2014): Impact of Economic Crises on Mental Health. Copenhagen: WHO Regional Office for Europe.

Yamamura, G. (2010): The Different Impacts of Socioeconomic Factors on Suicide between Males and Females. Applied Economic Letters 17(10): 1009-1012.

Open Access. This is an open-access article distributed under the terms of the Creative Commons Attribution-NonCommercial 4.0 International License (https:// creativecommons.org/licenses/by-nc/4.0/), which permits unrestricted use, distribution, and reproduction in any medium for non-commercial purposes, provided the original author and source are credited, a link to the CC License is provided, and changes - if any - are indicated. 